Warszawa 2019

PFLIT, no. 9(12), pt. 2: 201-215

ANNA GESICKA

Katedra Filologii Romańskiej

Uniwersytet Mikołaja Kopernika w Toruniu

\title{
„INTERTEKSTUALNA BIBLIOTEKA” FRANCISZKA VILLONA
}

Słowa kluczowe: Franciszek Villon, Legaty, Testament, intertekstualna biblioteka, topos Keywords: François Villon, Lais, Testament, intertextual library, topos

\section{THE 'INTERTEXTUAL LIBRARY’ OF FRANÇOIS VILLON}

S u m m a ry

In this article, I focus on the intertextual dimension of François Villon's poems: Lais and Testament. The 'intertextual library' is the internal knowledge that is used by the poet. I analyse intertextual references that appear as directly mentioned names or book titles and literary allusions easily identified by the reader. The principle behind their selection and juxtaposition in particular verses is the starting point for examining the function of their use from the perspective of the supposed author's intention.

Na temat Franciszka Villona, francuskiego piętnastowiecznego poety, napisano tak wiele, począwszy od XVI wieku, że chciałoby się powiedzieć - może już wszystko. Nawet poszczególne wersy bywały przez krytyków poddawane wnikliwej analizie i stanowiły materię artykułów ${ }^{1}$. Jednak nadal aktualne wydają się słowa, którymi w swoim czasie podsumował fenomen Villona jeden z jego wydawców i komentatorów, Pierre Michel: „Wszyscy dzisiejsi krytycy uznają zgodnie, że istnieje «tajemnica Villona», tak jak istnieje «tajemnica Homera» czy «tajemnica Szekspira»"2. Metody i klucze interpretacyjne, jakie

\footnotetext{
${ }^{1}$ Przede wszystkim: Jean Dufournet, Recherches sur le Testament de François Villon (Paris: Société d'Éditions d'Enseignement Supérieur, 1971) i Nouvelles recherches sur Villon (Paris: Champion, 1980). Uaktualniana bibliografia Villona np. na stronie https:/www.arlima.net/eh/ francois_villon.html, acc. 29.03.2018; cf. Dictionnaire des lettres françaises, Le Moyen Age, ed. Geneviève Hasenohr et Michel Zink (Paris: Fayard, 1992), 471-472.

${ }^{2}$ Pierre Michel, „Introduction générale. L'énigmatique Villon”, in François Villon, Poésies complètes, ed. Pierre Michel (Paris: Librairie Générale Française, 1972), XI.
} 
stosowano do analizy spuścizny Villona, zaskakują różnorodnością i rozpiętością perspektyw ${ }^{3}$ i dowodzą tyleż inwencji badaczy, co inspirującego potencjału samego dzieła. Ważne słowa padły w artykule Bronisława Geremka, używającego terminu „,villonologia”: „Mamy tu bowiem do czynienia z nieczęsto spotykanym przypadkiem, gdy badania akademickie służą legendzie, a wysiłek erudycji, nawet antykwarycznej, stanowi główne tworzywo mitologizacji postaci i dzieła"4. Jak jednak również zauważył Pierre Michel, wydaje się, że „chodzi nie o to, by znaleźć Villona, ale by go szukać”, co, trawestując, można by ująć następująco: chodzi nie o to, by zrozumieć Villona, ale by ciągle go analizować.

Niniejszy artykuł przypomni intertekstualny wymiar głównego dzieła Villona - Testamentu (Testament; inaczej - Grand Testament), aczkolwiek w kilku przypadkach odniosę się też do Legatów (Lais; inaczej - Petit Testament) ${ }^{6}$. Legaty, z 1556 roku, to poemat złożony z 320 wersów, zbudowany z ośmiowersowych zwrotek oktosylabicznych, zawierających, oprócz rozważań poety na temat przyczyny powstania poematu, legaty z wirtualnymi, satyrycznymi „darami”. Testament, napisany w 1461 roku, składa się z 2023 oktosylabicznych wersów, również w formie ośmiowersowych zwrotek, legatów bądź refleksji podmiotu lirycznego na różne tematy, przetykanych balladami lub innymi poetyckimi formami, które przeważnie również stanowią legat dedykowany określonemu odbiorcy z określoną intencją, poważną lub, najczęściej, satyryczną.

Termin „intertekstualność” rozumiany jest tu szeroko jako relacja międzytekstowa, choć w wielu miejscach odpowiada rozróżnieniu zaproponowanemu przez Gérarda Genette'a w Palimpsestach, gdzie stanowi jeden z typów relacji transtekstualnej, definiowany jako „relacja współobecności, zachodząca między dwoma bądź wieloma tekstami, to znaczy ejdetycznie, i najczęściej jako rzeczywista obecność jednego tekstu w drugim”, której formą „mniej eksplicytną i mniej literalną jest aluzja"7.

Wirtualna „intertekstualna biblioteka” to zinterioryzowany zasób wiedzy Villona (lub efektowny pozór wiedzy), z którego czerpie on pełnymi garściami i z dużą swadą. Villon to paryski klerk, który odebrał typowe wykształcenie,

\footnotetext{
${ }^{3}$ Cf. Jean Dufournet, Villon et sa fortune littéraire (Ducros: Saint Médart-en-Jalles, 1970).

${ }^{4}$ Bronisław Geremek, „Śmiech w cieniu szubienicy: o Villonie”, Znak, no. 8 (1983): 1268, http://www.mbc.malopolska.pl/dlibra/publication?id=67458\&tab $=3$ (acc. 08.03.2018).

${ }^{5}$ Pierre Michel, op. cit., XIX.

${ }^{6} \mathrm{Na}$ temat intertekstualnego wymiaru dzieła Villona wnikliwe studium napisała Jane H. M. Taylor, The Poetry of François Villon: Text and Context (Cambridge: Cambridge University Press, 2001). Autorka analizuje tam szczegółowo wiele z przywołanych w niniejszym artykule odniesień.

${ }^{7}$ Gérard Genette, Palimpsesty. Literatura drugiego stopnia, trans. Tomasz Stróżyński, Aleksander Milecki (Gdańsk: słowo/obraz terytoria, 2014), 7-8.
} 
uzyskując w 1449 roku tytuł bakałarza, a w 1452 roku kolejno licencjata i mistrza sztuk wyzwolonych (maître ès arts) ${ }^{8}$. Jego intelektualne zasoby obejmują, obok mniej lub lepiej przyswojonej wiedzy z zakresu Artes Liberales (stanowiącej dla średniowiecznego intelektualisty „minimalny kulturalny bagaż”9 ${ }^{9}$, jakieś wiadomości z zakresu Pisma Świętego, hagiografii, historii świata. Sam poeta przyznaje się w Testamencie do niezbyt pilnego studiowania. Villon czerpie ponadto ze źródeł literatury antycznej i francuskiej. Na temat oczytania Villona formułowano różne opinie. Niegdyś Fernand Desonay uważał, że literackie zasoby Villona nie są imponujące, oraz wskazywał, że odwołuje się on raczej do modnych „tematów fruwających w powietrzu” (np. związanych z teatrem: miraklami, farsami, itp.), których znajomość często jest powierzchowna i zawdzięcza się ją rozmowom, lekturze czy przypadkowi ${ }^{10}$. Bronisław Geremek pisze natomiast, że „twórczość Villona daje przede wszystkim świadectwo rozległej kultury literackiej i intelektualnej" ${ }^{\prime 1}$. Z kolei Jean-Claude Muhlethaler precyzyjnie wskazuje, że przy badaniu intertekstualnych relacji w Testamencie Villona należałoby mieć na względzie zwłaszcza teatr świecki, poezję Wielkich Retoryków i perspektywę rodzącego się już humanizmu ${ }^{12}$.

Wyznacznikami analizowanych $\mathrm{w}$ niniejszym artykule intertekstualnych odniesień będą wspomniane wprost nazwiska lub tytuły dzieł oraz literackie aluzje - jasne dla czytelnika. Zasada ich doboru i zestawienia w poszczególnych wierszach będzie punktem wyjścia do zastanowienia się nad funkcją ich użycia w perspektywie domniemanej intencji autorskiej.

Trzeba na wstępie zauważyć, że już sama literacka forma testamentu jest w szerokim znaczeniu intertekstualna, ponieważ „wpisuje się w tradycyjny ciąg i poważnych, i półżartobliwych poematów «pożegnalnych», tworzonych wcześniej przez wielu poetów [...]" ${ }^{13}$. Dominująca figura stylistyczna, którą posługuje się Villon czerpiąc ze swojej własnej intertekstualnej biblioteki, to enumeracja. W celu wzmocnienia semantycznego przekazu wylicza on ważne postaci lub akumuluje znane toposy, a czytelnikowi przypada zadanie czujnej lektury, jako że

${ }^{8}$ Dictionnaire des lettres françaises, 467. Na temat średniowiecznego stopnia maître ès arts vide Jacques Verger, „Pour une histoire de la Maîtrise es Arts au Moyen Age: quelques jalons”, Médiévales, no. 13 (1987): 117-130, https://www.persee.fr/doc/medi_0751-2708_1987_num_ 6_13_1086 (acc. 05.04.2018).

${ }^{9}$ Ibidem, 130.

${ }^{10}$ Fernand Desonay, Villon (Liège: Georges Thone, 1933), 30.

${ }^{11}$ Bronisław Geremek, op. cit., 1285.

${ }^{12}$ Jean-Claude Muhlethaler, Poétiques du quinzième siècle. Situation de François Villon et Michault Taillevent (Paris: Nizet, 1983), 3.

${ }^{13}$ Zaś „Legaty (czyli po prostu «zapisy testamentowe») to jakby mała wprawka do Testamentu [...]”. Jacek Kowalski, „Wstęp”, in François Villon, Les Lais. Legaty czyli Mały Testament, trans. Jacek Kowalski (Poznań: Studio Bąk, 1994), 9. 
w przypadku tego poety w sposób szczególny nie można mieć żadnej pewności co do swej interpretacyjnej intuicji. Nie da się naprawdę określić, na jakiej zasadzie i w jakim celu Villon, którego ekspresja poetycka zawiera w sobie sporo wieloznaczności ${ }^{14}$, maskę ${ }^{15}$ i wyznanie, ze swoim odbiorcą się bawi, i czy bawi się z nim w istocie. Gérard Gros uświadamia, że czasownik villoner lub viloner („villonować”) znaczy, między innymi, „Zwodzić” „zręcznie oszukać”, a rzeczownik villon oznacza „zręcznego złodzieja” lub „oszusta”. Krytyk uważa, że można by się zastanowić nad związkiem rdzenia tych słów z prowokacjami w stosunku do tradycji literackiej czy modeli estetycznych, jakie praktykuje poeta noszący przecież przybrane nazwisko Villona ${ }^{16}$. Modelowym adresatem niełatwych, wieloznacznych aluzji Villona odnoszących się do współczesności wydaje się mieszkaniec Paryża, bywalec modnych miejsc, zarazem obeznany politycznie i społecznie w istotnych kwestiach kraju i znający nazwiska wpływowych osób. Natomiast modelowy odbiorca kulturowych odniesień, nieustannie zresztą reeksploatowanych w całej średniowiecznej literaturze przy użyciu identycznych zabiegów retorycznych, to ówczesny „intelektualista”, klerk, który odebrał, jak poeta, scholastyczne wyższe wykształcenie ${ }^{17}$ oraz posiada podobną mu literacką kulturę. Adrian Armstrong i Sarah Kay, odwołując się do terminologii Riffaterre'a, piszą, że liczne odniesienia intertekstualne w Testamencie zakładają publiczność bardzo uświadomioną, stanowiącą „maleńką w stosunku do prawdziwych czytelników Villona" grupkę wtajemniczonych, zdolnych zwrócić uwagę na „agramatyczności” sugerujące, iż sensu wersów należy szukać w intertekstualnej grze ${ }^{18}$. Sam Franciszek Villon jest z kolei aż nadto modelowym twórcą-odtwórcą, jak wielokrotnie wskazywano ${ }^{19}$, i jego oryginalność jest mierzona wyznacznikami wykraczającymi poza schemat tematu i środków wyrazu.

${ }^{14}$ Jean Dufournet, Villon: ambiguité et carnaval (Paris: Champion, 1992); Claude Thiry, „Introduction”, in François Villon, Poésies complètes, ed. Claude Thiry (Paris: Librairie Générale Française, 1991), 23-26.

${ }^{15}$ Cf. Jacqueline Cerquiglini, „Le nouveau lyrisme (XIV $-\mathrm{XV}^{\mathrm{e}}$ siècle)”, in Précis de la littérature française du Moyen Age, ed. Daniel Poirion (Paris: PUF, 1983), 280-281; Jean-Claude Muhlethaler, op. cit., 57-64; Éric Méchoulan, „Les arts de rhétorique du XVe siècle: la théorie, masque de la theoria?", in Masques et déguisements dans la littérature médiévale, ed. Marie-Louise Ollier (Paris-Montréal: J. Vrin, 1988), 213-221.

${ }^{16}$ Gérard Gros, „Villon: le miroir d'un déclin?”, in Apogée et déclin (Cultures et civilisations médiévales), no. III (Paris: Presses de l'Université de Paris Sorbonne, 1993), 265.

${ }^{17}$ Jacques Le Goff, Les intellectuels au Moyen Age (Paris: Le Seuil, 2008), 4, 140; Bronisław Geremek, op. cit., 1286-1287.

${ }^{18}$ Adrian Armstrong, Sarah Kay, Une Muse savante? Poésie et savoir, du Roman de la Rose jusqu'aux grands rhétoriqueurs (Paris: Classiques Garnier, 2014), 228.

${ }^{19}$ Począwszy od klasycznego studium Italo Siciliano, François Villon et les thèmes poétiques du Moyen Age (Paris: Librairie Armand Colin, 1934). 
Najbardziej bezpośrednie i łatwe do wyodrębnienia intertekstualne odniesienia w poematach Villona ${ }^{20} \mathrm{z}$ grubsza można podzielić na przenikające się kategorie, z których ukazane tu zostaną reprezentatywne przykłady. Bardzo ważnym punktem odniesienia jest tradycyjnie Biblia ${ }^{21}$. W ujęciu satyrycznym przywołany został fragment psalmu (,Wnet Psałterz w dobrą porę chwytam, [...] / Y siodmy werset pilnie czytam, / Psalm: Deus laudem... dość sposobny...", T, VI ${ }^{22}$ ), którego treść sugeruje, że poeta życzy swemu wrogowi krótkiego życia i utraty majątku. Gdzie indziej, w celu zintensyfikowania pochlebczego charakteru życzeń skierowanych do króla Ludwika XI, w jednej strofie wymienia poeta wskaźniki pomyślnej egzystencji konotowane przez biblijne postaci: szczęście Jakuba (aluzja do snu z Księgi Rodzaju, zapowiedź licznego potomstwa), „cześć y chwałę23 Salomona, wiek Matuzalema (T, VIII). Jako pokorny chrześcijanin, ufny w zbawienie, pisze Villon o dostrzeganej w swym życiu Bożej interwencji:

Bóg, co emauskie wsparł pielgrzymy

(Iak Ewangelia opowiada)

Ukazał drogi kres pocieszny

Nadzieią krzepiąc moią żałośćc ${ }^{24}$ [T, XIII].

Podkreśla krzepiące Jezusowe umiłowanie biednych:

Mówię to w IEZUSOWYM duchu,

Który położył Bogatego

W ogniu, nie wcale w miętkim puchu,

Zaś trędowatych wyżey niego ${ }^{25}[\mathrm{~T}, \mathrm{LXXXII}]$.

${ }^{20}$ Objaśnienia - podobnej treści - kontekstu i charakteru intertekstualnych odniesień, które przywołuję w analizie, znajdują się w komentarzach do wersów u wszystkich autorów konsultowanych tu wydań: François Villon, Poésies complètes, ed. Pierre Michel, op. cit.; François Villon, Poésies complètes, ed. Claude Thiry (Paris: Librairie Générale Française, 1991); François Villon, Poésies, ed. Jean Dufournet, op. cit. Nie przywołuję każdorazowo źródła wiedzy.

${ }^{21} \mathrm{Na}$ temat wzajemnych wpływów Biblii i literatury świeckiej w międzynarodowym piśmiennictwie średniowiecznym i w liryce Villona, szczególnie w kontekście toposu Ubi sunt?, vide Étienne Gilson, „De la Bible à François Villon”, École pratique des hautes études, Section des sciences religieuses. Annuaire 1923-1924 (1922): 3-24, http://www.persee.fr/doc/ephe_0000-0002_ 1922_num_36_32_20056 (acc. 10.03.2018).

${ }^{22}$ Zapis tekstów źródłowych w nawiasie będzie następujący: L (Legaty) lub T (Testament), po przecinku rzymską cyfrą numer strofy (ta sama numeracja jest zachowana we wszystkich wydaniach). Jeśli nie podano inaczej, tłumaczenie fragmentów Legatów i Testamentu własne. Tu w przekładzie Tadeusza Boya-Żeleńskiego. Villon François, Wielki testament, trans. Tadeusz Żeleński (Boy), in Arcydzieła francuskiego średniowiecza, ed. Zygmunt Czerny (Warszawa: Państwowy Instytut Wydawniczy, 1968).

${ }^{23}$ Trans. Tadeusz Boy-Żeleński, op. cit.

${ }^{24}$ Trans. Tadeusz Boy-Żeleński, op. cit.

${ }^{25}$ Trans. Tadeusz Boy-Żeleński, op. cit. 
W funkcji przestrogi (a posteriori) przed popełnianiem błędów młodości odwołuje się poeta do Księgi Koheleta. Sam zbyt chętnie był się onegdaj zastosował do jej rad („Nadtom brał wiernie, co powiada / Mędrzec, y pismam wierzył słowu”26), w lekturze dość powierzchownej, nie bacząc na kolejne wersy wyraźnie przed głupotą młodości przestrzegające (T, XXVII). Zaś zrozumienie „wielkiego Credo" może być, w ironicznym ujęciu poety, miernikiem intelektualnych lub duchowych możliwości wysoko postawionych osób (T, CXXIX).

Z kolei w charakterze wyraźnie prześmiewczej zachęty do uprawiania miłości wbrew jej zgubnemu charakterowi - albo do uprawiania jej, skoro jest się tak nierozsądnym, by się angażować, pomimo zniechęcających przykładów („miłości dur ogłupia ludzi”27) - w Double ballade sur le mesme propos (u Boya-Żeleńskiego Podwóyna ballada $w$ tymże samym przedmiocie) wymienione zostały postaci biblijne znane jako „ofiary” miłości: Salomon, co nią ogłupiony „wszedł w pogany” "28, Samson, co przez nią „stracił swe okulary”29, Dawid, który dla miłości „zapomniał o bojaźni Bożej”, jego syn Amnon, który pohańbił własną siostrę „udając, że je tarteczki”, Herod, co „świętego Jana Baptystę ściął / Dla śpiewów, skoków i piosneczek". Równie prześmiewczy charakter ma potraktowanie psalmu jako ironicznego legatu dla człowieka, którego kontekst całej strofy ukazuje jako pozbawionego talentu i niefortunnego w miłości: „Wraz De profundis, pieśń żałośną / Na dawne iego miłowanie" ${ }^{30}$ (T, XCIV). W Ballade et oraison (u Boya Ballada y modlitwa), dedykowanej paryskiemu prawnikowi znanemu $\mathrm{z}$ upodobania do picia, cała pierwsza zwrotka to apostrofa do kojarzonych $\mathrm{z}$ alkoholem bohaterów biblijnych: Noego, Lota, Architryklina.

Drugą kategorię stanowią liczne odwołania do kultury świeckiej. Są to powszechnie znane nazwiska-symbole, często z dopełniającą krótką charakterystyką, pasującą do poetyckiej koncepcji utworu. W charakterze autorytetu zostaje więc przywołany już w pierwszej zwrotce Legatów Wegecjusz: „Mądry Rzymianin, wielki doradca"31 (L, I). Jako dowód na erudycję poety występuje oczywiście Arystoteles (w średniowiecznym postrzeganiu Filozof sensu stricto), aczkolwiek ukazanie, pod pozorem psychologicznej „autoanalizy” podmiotu, w krzywym zwierciadle scholastycznej maniery ${ }^{32}$ wskazuje na satyryczny cel wiersza:

${ }^{26}$ Trans. Tadeusz Boy-Żeleński, op. cit.

${ }^{27}$ Trans. Tadeusz Boy-Żeleński, op. cit.

${ }^{28}$ Trans. Tadeusz Boy-Żeleński, op. cit.

${ }^{29}$ U Boya thumaczenie tego wersu pomija postać Samsona zupełnie: „Naymędrszy boday sie spaskudzi...”. W oryginale użycie słowa „okulary” (lunetes) zamiast „oczy” wyraźnie podkreśla prześmiewczy charakter ballady. Cytaty francuskie za edycją Pierre’a Michela.

${ }^{30}$ Trans. Tadeusz Boy-Żeleński, op. cit.

${ }^{31}$ Cf. Ernst Robert Curtius, Literatura europejska i łacińskie średniowiecze, trans. Andrzej Borowski (Kraków: Universitas, 1997), 58-59, 63-67.

${ }^{32}$ Cf. Bronisław Geremek, op. cit., 1287; Jacques Le Goff, op. cit., 172. 
Znikła też i estymatywa,

Z której się perspektywa rodzi,

Symulatywa, formatywa,

Przez defekt których człek odchodzi

Od zmysłów, wpadłszy w omamienie,

Aż go jak lunatyka niesie.

Czytałem o tym, mam wrażenie,

Bodajże w Arystotelesie ${ }^{33}$ [L, XXXVII].

$\mathrm{Z}$ podobną intencją popisania się, w podobnie ironicznym duchu, ukazuje poeta wyższość doświadczenia nad jałowością wiedzy uniwersyteckiej:

\author{
Cierpienie, bakalarstwo wraże, \\ Rozum otwarło mi, do biesa, \\ Barziey niż wszytkie komentarze \\ Nad Arystotem Awerresa ${ }^{34}$ [T, XII].
}

Natomiast wiedzą prawniczą kanoniczną popisuje się Villon odwołując się do Decretum Gratiani (T, LXII).

Bohaterami kilkustrofowej umoralniającej opowieści są Aleksander Wielki i niejaki Diomedes. Aleksander jest jednocześnie bardzo ważną figurą w literaturze francuskiego średniowiecza; stanowi nowy typ bohatera powieściowego, łączącego epicką dzielność z zapałem do wiedzy i wrażliwością na miłość ${ }^{35}$. Przytoczona anegdotka o Diomedesie, morskim piracie, znana jest $\mathrm{z}$ utworów literatury antycznej i średniowiecznej, aczkolwiek akurat nie ze źródła, na które erudycyjnie powołuje się Villon ${ }^{36}$ („Walery nam zaświadcza o tem, / Wielkim wołany przez Rzym cały" ${ }^{37}, \mathrm{~T}, \mathrm{XX}$ ). Konfrontacja postaw bohaterów uwidoczniona w dialogu służy zilustrowaniu życiowej mądrości, którą dzieli się poeta, dokonując satyrycznego przewartościowania klasyfikacji dobra i zła w zależności od posiadanych dóbr (na małą skalę działa zbójca, na wielką - cesarz, T, XVIII). Jednocześnie pokazuje, że mędrcem można być niezależnie od kondycji społecznej: „Gdy cysarz dobrze to rzeczenie / Diomedesowe w myśli zważył: / «Dolę twą (prawi) wnet odmienię / Lichą na dobrą». Y tak zdarzył"38. Jest to zarazem lekcja równości, gdyż cesarz od tej pory wszystkich ludzi traktował godnie, „jak prawdziwy człowiek” (T, XX).

\footnotetext{
${ }^{33}$ Trans. Jacek Kowalski, op. cit.

${ }^{34}$ Trans. Tadeusz Boy-Żeleński, op. cit.

${ }^{35}$ Emmanuèle Baumgartner, Charles Méla, „La mise en roman”, in Précis de la littérature française du Moyen Age, ed. Daniel Poirion (Paris: PUF, 1983), 105.

${ }^{36}$ Jean Dufournet, op. cit., 223.

${ }^{37}$ Trans. Tadeusz Boy-Żeleński, op. cit.

${ }^{38}$ Trans. Tadeusz Boy-Żeleński, op. cit.
} 
Jako ilustracja innej mądrości, tym razem o niszczącej sile miłości dotykającej każdego, w słynnej nostalgicznej balladzie Ballade des dames du temps jadis (u Boya Ballada o paniach minionego czasu) pomiędzy ofiarami pojawiają się między innymi także nazwiska uczonych:

Gdzie jest przemądra Heloiza,

Z powodu której Piotr Abelard,

Wytrzebion został [...]?

Podobnie, gdzie jest ta królowa,

Co zażądała, by Burydan

W Sekwanę w worku rzucon został?

Swą smutną historię Abelard sam opowiedział w Historia calamitatum mearum. Natomiast słynnego scholastycznego filozofa Jana Burydana późniejsza legenda wiązała z seksualnymi orgiami w wieży de Nesle, organizowanymi przez Małgorzatę Burgundzką, do których Villon wydaje się nawiązywać ${ }^{39}$. W tej samej balladzie pomiędzy pięknymi paniami pojawia się imię Alcybiadesa, w wiekach średnich uważanego za kobietę $e^{40}$.

Najbogatszym źródłem intertekstualnych odniesień pozostaje dla Villona literatura. Poeta przypomina nazwiska autorów i bohaterów literackich oraz przywołuje i rozwija znane toposy. Bohaterowie literaccy to w pierwszym rzędzie postaci mitologiczne. Przywoływana już Ballade des dames du temps jadis wprowadzona jest zwrotką wspominającą najsłynniejszą parę starożytnych kochanków: „Umarł y Paris, y Helena”"41 (T, XL). W samej balladzie, i w tej samej funkcji ofiary miłości, pojawia się nieszczęśliwa nimfa: „Echo, co gada, gdy głos wydasz / Gdzieś ponad rzeką, ponad stawem”, a w funkcji sprawczyni nieszczęścia - królowa przyrównana do złowrogich kusicielek z Odysei: „Królowa Blanka, iak liliia, / Syrenim głosem zawodząca" ${ }^{42}$. W innej, wzmiankowanej już Double ballade sur le mesme propos, w której także wymienione zostały ofiary miłości - aczkolwiek z szyderczą intencją, widoczną chociażby w lekkim modyfikowaniu uznanych wersji - figurują przykłady pechowych mitycznych kochanków: Orfeusz „słodki minstrel”, co „naraził się morderczemu / Psu Cerberowi o czterech głowach”, Narcyz „młodzian pięknolicy” ${ }^{43}$ co „w studni się głębokiej utopił / Dla miłowania swych miłostek”, Sardana „xiążę niezbyt słabe, / Co Kretę wyspę zawoiował, / Rad był się przeinaczyć w babę, / Iżby śród dziewcząt dokazował" ${ }^{4}$. Inny syn Priama przypomniany został jako element porównania

\footnotetext{
${ }^{39}$ Vide Jean Dufournet, op. cit., 216.

${ }^{40}$ Cf. Ernst Robert Curtius, op. cit., 413.

${ }^{41}$ Trans. Tadeusz Boy-Żeleński, op. cit.

${ }^{42}$ Trans. Tadeusz Boy-Żeleński, op. cit.

${ }^{43}$ Trans. Tadeusz Boy-Żeleński, op. cit.

${ }^{44}$ Trans. Tadeusz Boy-Żeleński, op. cit.
} 
- poeta chwali adresata ballady, który niegdyś umiał zawalczyć o swą przyszłą żonę, iż „tak zadziałał dobrze [...] / jak nigdy Hektor” (T, CXXXIX).

Rozpoznawalne figury literatury średniowiecznej, protagoniści bądź autorzy, pojawiają się w podobnych funkcjach, zwłaszcza jako przykład ilustrujący poetycki przekaz. W Ballade des seigneurs du temps jadis (u Boya Ballada o panach dawnego czasu prowadzaca daley ten sam przedmiot), na podobnej zasadzie co w Balladzie o paniach minionego czasu, wymienia Villon ważne postaci historyczne, ukazując je jako zwykłych figurantów w korowodzie przemijania. Pytanie refrenu: „Kędy Szarlemań jest waleczny?” 45 odnosi się oczywiście przede wszystkim do Karola Wielkiego jako cesarza, ale tym specjalnym miejscem w balladzie poeta honoruje też bohatera epickiej legendy, będącego szczególnie rozpoznawalnym symbolem wielkości. Ballade pour prier Nostre Dame (u Boya Ballada iaka Wilon napisal na prośbe swey matki, aby ubłagać łaski Nayświętszey Panny) to włożona w usta prostej kobiety ${ }^{46}$ modlitwa, kwintesencja ludowej pobożności. Dwie postaci ikonograficzne i literackie, Maria Egipcjanka (nawrócona aleksandryjska prostytutka ${ }^{47}$ ) i klerk Teofil, który podpisał pakt z Diabłem, to przykłady grzeszników, w życiu których doszło do zbawiennej interwencji Matki Boskiej. Nazwisko epickiego bohatera Ogiera Duńczyka było, między innymi, symbolem seksualnej werwy i płodności. U Villona występuje on jako punkt odniesienia, złośliwie uwypuklający impotencję adresata legatu: „Poza tym, niech po stokroć tryka, / Że niczem rycerz Ogier Wielki”"48 (T, CLXVII). W kolejnym legacie skierowanym do nieszczęśliwych (też w znaczeniu impotentów) kochanków (T, CLXVIII) pojawia się nazwisko będące znakiem odsyłającym do impasów miłości dwornej. Chodzi o autora z przełomu XIV i XV wieku, „mistrza Alaina Chartiera”, twórcy, między innymi, przewrotnego poematu La Belle Dame sans Mercy (Piękna Dama bez Litości); Villon bezpośrednio nawiązuje tu do znanych wersów z tego utworu.

Ważnym powracającym intertekstualnym odniesieniem jest Powieść o Róży. Villon powołuje się na autorytet autora jej drugiej, polemicznej części, Jeana de Meun, gdy rozpisuje się w satyrycznym tonie o faryzejskiej postawie zakonników: „Mistrz Ian Mehuński też dworować / Ważył się z pilney mniszey krzoski” (T, CXVIII) oraz gdy zachęca do wybaczania niegdysiejszym „młodym sercom”

${ }^{45}$ Trans. Tadeusz Boy-Żeleński, op. cit.

${ }^{46}$ Cf. Gérard Gros, „La vieille femme dans le Testament Villon. Étude sur un caractère”, in Les niveaux de vie au Moyen Âge: mesures, perceptions et représentations, ed. Jean-Pierre Sosson, Claude Thiry, Sandrine Thonon, Tania van Hemelryck (Louvain-la-Neuve: Academia-Bruylant, 1999), 106-109.

${ }^{47}$ Jean Dufournet, op. cit., 224. Cf. strofa XCII, gdzie w zawołaniu „Na świętą Marię nadobną!" (par sainte Marie la belle!) krytycy dopatrują się odwołania do nawróconej grzesznicy (Pierre Michel, op. cit., 122), ale też do Matki Boskiej (Claude Thiry, op. cit., 164).

${ }^{48}$ Trans. Tadeusz Boy-Żeleński, op. cit. 
błędów ich młodości: „Y, jak ów piękny Romans Róży / Powiada (ba, nie bez powodu!) [...] / iż trzeba płochość serca z młodu / Darować [...]"49 (T, XV). Prawdopodobnie także czyni aluzję do tego utworu, gdy dedykuje jeden z legatów Testamentu „drogiej Róży”. Alegoryczne imię zostało tu użyte z ironiczną intencją, ponieważ poeta sugeruje seksualną rozwiązłość i finansową pazerność adresatki (T, XC). Do znanych przekonań Jeana de Meun na temat roli prokreacji nawiązuje poeta wyraźnie w Ballade pour Robert d'Estouteville (u Boya Ballada iaka Wilon udarowat pewnego świeżo ożenionego szlachcica, iżby postat ia swey matżonce, która zdobyt sobie mieczem): „Takoż nie stracę ziarna, co go sieię / $\mathrm{W}$ twey roli, którą w pacht od Boga wziąłem; / Wnet owoc luby z niey mi się zaśmieie; / Y oto, czemu iesteśmy tu społem"50.

Wierny literackiej manierze swego czasu, snuje Villon wariacje na temat znanych toposów. Wszystkie w zasadzie wpisują się w tematykę przemijania i śmierci ${ }^{51}$, z zaakcentowaniem różnych jej aspektów. Topos tempus fugit w ujęciu Villona podkreśla w szczególności szybkość procesu. Tak poeta mówi o minionym niezauważalnie czasie młodości: „I nie na piechotę odszedł / Ni na koniu: trudno! jak zatem? / Nagle uleciał / I niczego w darze mi nie pozostawił" (T, XXIII), „Dnie moie tako się rozbiegły / Iako, Hiob mówi, w lnianem płotnie / Nitki, gdy słomy garść zażegłey / Tkacz przytknie doń [...]”52 (T, XXVIII).

Topos danse macabre, wyrażający równość wszystkich wobec nieuchronnej śmierci, został dosadnie wyrażony przez Villona ${ }^{53}$, i ze swadą przetłumaczony przez Boya, w słynnej strofie XXXIX Testamentu:

Wiem, że bogate y ubogie,

Mądre, szalone, świeckie, xiędze,

Hoyne i skape, tanie, drogie,

Małe y duże, pychy, nędze ${ }^{54}$,

Damy z kołnierzem w zmyślne rurki -

Iakietamkolwiek godło czyie -

Iedwabie czy siermiężne burki:

Wszytko dołapi śmierć za szyie.

${ }^{49}$ Trans. Tadeusz Boy-Żeleński, op. cit.

${ }^{50}$ Trans. Tadeusz Boy-Żeleński, op. cit. Dosłowne tłumaczenie bardziej jeszcze każe myśleć o Jeanie de Meun: „Wtedy nie stracę ziarna, co je sieję, / Na twym polu, gdy owoc mi podobny. / Bóg nakazuje, abym je uprawiał; / To cel, dla którego jesteśmy razem”.

${ }^{51}$ Cf. Johan Huizinga, Jesień średniowiecza, trans. Tadeusz Brzostkowski (Warszawa: Państwowy Instytut Wydawniczy, 1996), 168-183.

${ }^{52}$ Trans. Tadeusz Boy-Żeleński, op. cit.

${ }^{53} \mathrm{Na}$ temat złożoności użycia tego toposu przez Villona vide Jane H. M. Taylor, „,Villon et la danse macabré: 'défamiliarisation d'un mythe"', in Pour une mythologie du Moyen Age, ed. Laurence Harf-Lancner et Dominique Boutet (Paris: École Normale Supérieure, 1988), 179-196.

${ }^{54}$ Cytowane thumaczenie tej strofy przez Boya jest piękne i wierne, ale w tym wersie zabrakło rozróżnienia, które jest u Villona, na „piękne i brzydkie”. 
Inny topos należący do semantycznego pola przemijania to odwieczne pytanie ubi est? Zadaje je również Villon, wspominając kobiety i mężczyzn, którzy niegdyś żyli, kochali, odgrywali ważne role i byli sławni, następnie przeminęli, a my nie wiemy, gdzie się podziali. Zapadają w pamięć metafory z Ballade des dames du temps jadis, z pierwszego wersu: „Powiedz mi, gdzie y w iakiey ziemi, / Iest [...]” i refrenu: „Ach, gdzie są niegdysiejsze śniegi?” 55 , w którym Boy, nie wiadomo czemu, nostalgicznym wykrzyknieniem zastąpił oryginalny spójnik, dobrze wyrażający fundamentalną niemożność udzielenia odpowiedzi na to pytanie: „Lecz gdzie są niegdysiejsze śniegi?”. Ballade des seigneurs du temps jadis kontynuuje tę samą refleksję, ale tu Villon dokonuje wyboru prostej enumeracji postaci, nie siląc się na metafory czy oryginalnie sformułowane zapytania. Natomiast korzysta $\mathrm{z}$ innej popularnej wariacji toposu ubi est. Podmiotem Les regrets de la Belle Heaulmière (u Boya Żale piękney Ptatnerki dobrze iuż sięgniętey przez starość) czyni poeta starą kobietę, słynną paryską kurtyzanę, przeglądającą się w lustrze i mierzącą się z niszczycielskim piętnem czasu na swoim niegdyś atrakcyjnym ciele. Odnajdujemy tu topos zwierciadła oraz formułę wyrażającą uniwersalne zdumienie: qu'elle fus, qu'elle devenue! (,jaką byłam, a jaką się stałam!”) ${ }^{56}$ : „Cóż się z tem czółkiem stało lśniącem, / Kosą blond, brwią wygiętą w górę, / Spoźrzeniem radem a palącem, / Co lazło chłopu het, za skórę?"57 (T, LII). To tylko fragment rozważań kobiety na temat poszczególnych części jej ciała.

Kolejny topos, powszechnie pojawiający się w odniesieniu do idei śmierci (podobnie jak formuła ubi est) ${ }^{58}$, to teologiczna idea vanitas vanitatum. Pojawia się w Testamencie w formie znanej formuly: „Co z ziemi, w ziemię się obraca; / Wszelka rzecz, słusznie mówią pono, / Chętnie do swego mieścca wraca"59 (T, LXXXVI). Poeta, jak zwykle niejednoznaczny, traktuje świadomość marności wszechrzeczy jako źródło przewrotnego pocieszenia:

\footnotetext{
Świat ten, zaiste, nie iest wieczny,

Iako łupieżca możny mniema;

Wszytkich miecz czeka obosieczny;

Lepszey pociechy ponoś nie ma

Staremu, co za młodu słynął

$\mathrm{Z}$ uciesznych figlów y trefności; $[\ldots]^{60}[\mathrm{~T}, \mathrm{XLIII}]$.
}

\footnotetext{
${ }^{55}$ Trans. Tadeusz Boy-Żeleński, op. cit.

${ }^{56}$ Cf. Italo Siciliano, op. cit., 383-396.

${ }^{57}$ Trans. Tadeusz Boy-Żeleński, op. cit.

${ }^{58}$ Étienne Gilson, op. cit., 11.

${ }^{59}$ Trans. Tadeusz Boy-Żeleński, op. cit.

${ }^{60}$ Trans. Tadeusz Boy-Żeleński, op. cit.
} 
Legaty to parodia topiki fin'amors, tzw. miłości dwornej ${ }^{61}$. To burleskowy testament domniemanego rycerza, nieszczęśliwie zakochanego w bezlitosnej Damie, który decyduje się na wyjazd w dalekie kraje, zostawiając ukochanej swe serce jako relikwię, a „przyjaciołom” (w rzeczywistości to cele ostrza jego satyry), w kolejnych legatach, szydercze, wirtualne „dobra”. Są domniemania, że poemat to literackie alibi poety, który musi opuścić pilnie Paryż po włamaniu do Kolegium Nawarskiego, którego dokonał z przyjaciółmi ${ }^{62}$. Claude Thiry pisze, że to, co w Legatach naprawdę pozostawił Villon, to „galeria karykatur - począwszy od jego własnej”, zniszczonego przeżyciami kochanka-męczennika ${ }^{63}$. W Testamencie Villon kontynuuje parodię miłości dwornej. W obu utworach poeta posługuje się zgrabnymi retorycznymi zabiegami: używa wyrażeń naprawdę należących do języka dwornego, zastępuje je słowami nienależącymi do tego kodu, dokonuje wtrąceń parodiujących stylistykę dwornej miłości bądź wzmacniających efekt komiczny, miesza ze sobą przeciwstawne rejestry językowe. Ironizując na temat swych własnych domniemanych nieszczęść miłosnych (przeważnie są to dosadnie ukazane niepowodzenia erotyczne), posiłkuje się poeta w satyrycznym duchu rozpoznawalną frazeologią. Kontynuuje odwoływanie do kluczowych toposów, sam występując konsekwentnie w roli kochanka-męczennika. Jest to zatem wierna służba Damie oraz podkreślanie cierpień miłości: „Gdyby ta, którey’m niegdy służył / Z wiernego serca, szczerey woley, / Przez którą'm tyle męki użył / Y wycirpiałem moc złey doley [...]”"64 (T, LXV). Męczeństwo odrzucenia: „Tak oto mnie ze szczętem Miłowania wyzyskały” (T, LXIX). Deklaracja odrzucenia miłości oraz śmierci z miłości: „Neguję Miłość i nią gardze”, „Śmierć mnie przez nią dopada”. Rezygnacja ze śpiewu, co w języku dwornej miłości oznacza rezygnację z miłości: „Wiolę mą precz już odłożyłem, / Za Kochankami już nie pójdę: / Nawet jeśli byłem jednym z nich, / Ogłaszam, że tak już nie jest” (T, LXX). Ballade de Villon à s'amye (u Boya Ballada Wilona dla swey miłey) ilustruje topos zwodniczego uroku Damy bez Litości i topos spojrzenia: „Fałszywa ${ }^{65}$ piękności, co tyle mnie kosztujesz”, „Oczy bezlitosne, czyż Prawo nie każe, / Miast go tak dręczyć, wspomóc nieboraka?”. Parodystyczne potraktowanie topiki dwornej przez Villona syntetycznie ilustruje pierwsza strofa Ballade de la Grosse

${ }^{61}$ Temu zagadnieniu poświęcono osobne liczne studia, np. Françoise Giordani, „Quelques remarques sur l'art de la parodie chez Villon et Rabelais: Deux pastiches de la psychologie et du style amoureux dans le Lais et Pantagruel", in Mélanges de langue et littérature françaises offerts à Pierre Jonin (Aix-en-Provence: Presses universitaires de Provence, 1979), 267-285; Albert Barrera-Vidal, „Amour courtois et parodie littéraire chez François Villon”, in Revue belge de philologie et d'histoire, no. 53, fasc. 3 (1975): 696-725.

${ }^{62}$ Jacek Kowalski, op. cit., 7.

${ }^{63}$ Claude Thiry, „Introduction”, op. cit., 16.

${ }^{64}$ Trans. Tadeusz Boy-Żeleński, op. cit.

${ }^{65}$ Użycie tego „niedwornego” przymiotnika sugeruje parodystyczną intencję poety. 
Margot (u Boya $O$ Wilonie $i$ Grubey Matgośce), gdzie mieszają się dwa rejestry języka, dworny i potoczny: „Ieśli ją kocham i służę z ochoty, / Zaliż kpem przez to y pluchą się zdawam? / Ma ona w sobie, wierę, piękne cnoty, / Głośno iey miłość i służby wyznawam; [...]"66. W ironicznym ,auto-epitafium” przedstawia Villon sam siebie jako ofiarę miłości: „Tu legł, z Amora dłoni srogiey, / Z sercem boleśnie skaleczonem, / Żaczyna lichy y ubogi, / Co był Franciszkiem zwan Wilonem" ${ }^{67}$ (T, CLXXVIII). W Autre Ballade (u Boya Ballada stużaca na zakończenie) tak oto brzmi zaproszenie poety na ceremonię jego ostatniego pożegnania: „Przybądźcie wznieść pogrzebny lament, / Gdy usłyszycie granie dzwona. / Miłości pomarł on ofiarą; [...] / Miłości pomarł męczennikiem [...]”.

Wydaje się, że podstawowym kryterium zarówno selekcji - z jego wewnętrznej „intertekstualnej biblioteki” - postaci i odniesień, jak i sposobu ich zestawienia w ramach enumeracji, jest osąd poety, że właśnie one najskuteczniej wypełnią sensotwórczy cel (jakkolwiek byłby przewrotny), który sobie postawił. Czytelnik nie może być w żaden sposób pewien, czy dobrze odczytał autorską intencję, zwłaszcza że aluzje są często niekompletne a cytaty błędnie przytoczone ${ }^{68}$. Przegląd przykładów podanych w tym artykule pozwala jednak wyodrębnić kilka wyrazistych funkcji odniesień zastosowanych w Legatach i Testamencie.

Postaci z „katalogu” kultury występują w wersach Villona w funkcji autorytetu; mają, być może, wywołać wrażenie erudycji (czytelnik odnosi wręcz wrażenie, że autor się nią popisuje), ale ich głównym zadaniem jest wspomożenie umoralniającej intencji lub zilustrowanie przekazywanej życiowej mądrości. Przykłady zaczerpnięte z Biblii to postaci przywołane często w ujęciu satyrycznym (np. jako przewrotna - bo z odwróconą intencją - zachęta). Ich zadaniem jest wzmocnienie wymowy wiersza (np. jego pochlebczego czy szyderczego charakteru). Odniesienia do świętych tekstów także w naturalny sposób wzmacniają poważniejszy głos Villona-chrześcijanina, wyrażającego dziecięcą ufność w zbawienie bądź udzielającego przestrogi dowodzącej jego świadomości co do hierarchii rzeczy. Przytoczone „fakty” z życia biblijnych bohaterów, czasem celowo zmodyfikowane, służą jako przestroga (przeważnie podchwytliwa) lub ilustracja prezentowanej życiowej postawy.

Literatura to najbogatszy „katalog” Villonowskiej ,intertekstualnej biblioteki”. Postaci z mitologii czy bohaterowie lub autorzy tekstów średniowiecznych oraz literackie aluzje pełnią $w$ wierszach podobną egzemplifikacyjną funkcję - ilustrują poetycki przekaz, stanowiąc rozpoznawalny dla odbiorcy znak bądź punkt odniesienia uwypuklający myśl przewodnią. Silnie obecne w Testamencie cztery wanitatywne toposy, pomimo lekkiego tonu wypowiedzi, szczególnie

\footnotetext{
${ }^{66}$ Trans. Tadeusz Boy-Żeleński, op. cit.

${ }^{67}$ Trans. Tadeusz Boy-Żeleński, op. cit.

${ }^{68}$ Adrian Armstrong, Sarah Kay, op. cit., 199-200, 206.
} 
skłaniają do refleksji, natomiast oryginalnie sparodiowana topika dwornego kodu miłosnego, rozsiana po Legatach i Testamencie, ma rozbawić świadomego odbiorcę. Jak napisał Giuseppe-Antonio Brunelli, w poezji Villona „nie brakuje żadnej nuty”, aczkolwiek ,jego bohater, to znaczy on sam, jest zasadniczo bohaterem komicznym" ${ }^{69}$. Ale pomimo wszystko, nadal pociągający wydaje się myślowy stereotyp, że istota lirycznych wyznań Villona streszcza się być może w innej intertekstualnej formule - w znanej z twórczości wcześniejszych poetów, a użytej przez Villona w charakterze ironicznej „autodefinicji”, słynnej antytezie „śmieję się przez łzy” (Poésies diverses, Ballade du concours de Blois).

\section{Bibliografia}

Arlima, https://www.arlima.net/eh/francois_villon.html (acc. 29.03.2018).

Armstrong, Adrian et Sarah Kay. Une Muse savante? Poésie et savoir, du Roman de la Rose jusqu'aux grands rhétoriqueurs. Paris: Classiques Garnier, 2014.

Barrera-Vidal, Albert, „Amour courtois et parodie littéraire chez François Villon”. Revue belge de philologie et d'histoire, no. 53, fasc. 3 (1975): 696-725.

Curtius, Ernst Robert. Literatura europejska i łacińskie średniowiecze, trans. Andrzej Borowski. Kraków: Universitas, 1997.

Desonay, Fernand. Villon. Liège: Georges Thone, 1933.

Dufournet, Jean. Villon et sa fortune littéraire. Ducros: Saint Médart-en-Jalles, 1970.

Dufournet, Jean. Recherches sur le Testament de François Villon. Paris: Société d'Éditions d'Enseignement Supérieur, 1971.

Dufournet, Jean. Nouvelles recherches sur Villon. Paris: Champion, 1980.

Dufournet, Jean. Villon: ambiguité et carnaval. Paris: Champion, 1992.

Genette, Gérard. Palimpsesty. Literatura drugiego stopnia, trans. Tomasz Stróżyński, Aleksander Milecki. Gdańsk: słowo/obraz terytoria, 2014.

Geremek, Bronisław. „Śmiech w cieniu szubienicy. O Villonie”, Znak, no. 8 (1983): 1266-1293 , http://www.mbc.malopolska.pl/dlibra/publication?id=67458\&tab=3 (acc. 08.03 . 2018).

Gilson, Etienne. „De la Bible à François Villon”. École pratique des hautes études, Section des sciences religieuses. Annuaire 1923-1924 (1922): 3-24, http://www.persee.fr/doc/ ephe_0000-0002_1922_num_36_32_20056 (acc. 10.03.2018).

Giordani, Françoise. „Quelques remarques sur l'art de la parodie chez Villon et Rabelais. Deux pastiches de la psychologie et du style amoureux dans le Lais et Pantagruel". In Mélanges de langue et littérature françaises offerts à Pierre Jonin. Aix-en-Provence: Presses universitaires de Provence, 1979, 267-285.

Gros, Gérard. „La vieille femme dans le Testament Villon. Étude sur un caractère”. In Les niveaux de vie au Moyen Âge. Mesures, perceptions et représentations, ed. Jean-Pierre Sosson, Claude Thiry, Sandrine Thonon, Tania van Hemelryck. Louvain-la-Neuve: Academia-Bruylant, 1999, 105-122.

${ }^{69}$ Dictionnaire des lettres françaises, op. cit., 470. 
Gros, Gérard. „Villon. Le miroir d'un déclin?”. In Apogée et déclin (Cultures et civilisations médiévales), no. III, Paris: Presses de l'Université de Paris Sorbonne (1993): $258-269$.

Hasenohr, Geneviève, et Michel Zink, ed. Dictionnaire des lettres françaises, Le Moyen Age. Paris: Fayard, Livre de Poche, 1992.

Huizinga, Johan. Jesień średniowiecza, trans. Tadeusz Brzostkowski. Warszawa: Państwowy Instytut Wydawniczy, 1996.

Kowalski, Jacek. „Wstęp”. In François Villon, Les Lais. Legaty czyli Mały Testament, trans. Jacek Kowalski. Poznań: Studio Bąk, 1994.

Le Goff, Jacques. Les intellectuels au Moyen Age. Paris: Seuil, 2008.

Méchoulan, Éric. „Les arts de rhétorique du XVe siècle. La théorie, masque de la theoria?". In Masques et déguisements dans la littérature médiévale, ed. Marie-Louise Ollier. Paris-Montréal: J. Vrin, 1988, 213-221.

Michel, Pierre ed. Villon, Poésies complètes. Paris: Librairie Générale Française, 1972.

Muhlethaler, Jean-Claude. Poétiques du quinzième siècle. Situation de François Villon et Michault Taillevent. Paris: Nizet, 1983.

Poirion, Daniel ed. Précis de la littérature française du Moyen Age. Paris: PUF, 1983.

Siciliano, Italo. François Villon et les thèmes poétiques du Moyen Age. Paris: Librairie Armand Colin, 1934.

Taylor, Jane H. M. „Villon et la danse macabré: ‘défamiliarisation d'un mythe”. In Pour une mythologie du Moyen Age, ed. Laurence Harf-Lancner et Dominique Boutet. Paris: École Normale Supérieure, 1988, 179-196.

Taylor, Jane H. M. The Poetry of François Villon. Text and Context. Cambridge: Cambridge University Press, 2001.

Thiry, Claude, ed. François Villon, Poésies complètes. Paris: Librairie Générale Française, 1991.

Verger, Jacques. „Pour une histoire de la Maîtrise es Arts au Moyen Age. Quelques jalons". Médiévales, no. 13 (1987): 117-130, https://www.persee.fr/doc/medi_07512708_1987_num_6_13_1086 (acc. 05.04.2018).

Villon François, Wielki testament, trans. Tadeusz Żeleński (Boy). In Arcydzieła francuskiego średniowiecza, ed. Zygmunt Czerny. Warszawa: Państwowy Instytut Wydawniczy, 1968. 